Wojciech Zalewski

Uniwersytet Gdański

wojciech.zalewski@prawo.ug.edu.pl

\title{
Sprawiedliwość naprawcza - formą demokracji deliberatywnej?
}

\author{
Restorative Justice - a Form of Deliberative Democracy?
}

\begin{abstract}
Modern democracy is in crisis. Citizens feel alienated, overlooked, unappreciated. The way out of the crisis, in the opinion of many, is by increasing the public role in democratic processes through civil participation. Citizens want to be involved not only in the process of legislation, but also in the application of the law. Today the court is no longer Dworkin's "capital of the law". There are alternatives to judicial resolutions, including restorative justice. Restorative justice is one of the modern forms of implementation of the deliberative democracy's postulates.
\end{abstract}

Keywords: restorative justice, deliberative democracy, criminal law

Słowa kluczowe: sprawiedliwość naprawcza, demokracja deliberacyjna, prawo karne

Każda forma rządu wymaga legitymizacji, czyli upoważnienia do działania. Za legitymizację uznaje się „uprawnienie rządzących do podejmowania wiążących decyzji, przy równoczesnej aprobacie rządzonych"'. Seymour Martin Lipset stwierdza, że legitymizacja obejmuje zdolność systemu do wytworzenia i podtrzymywania przekonania, że istniejące instytucje polityczne są dla społeczeństwa najlepsze. Poszczególne grupy uważają system polityczny za posiadający legitymizację na podstawie tego, jak system wartości systemu odpowiada ich wartościom² ${ }^{2}$. Legitymację do karania można wywodzić z różnych źródeł: dawniej wierzono, że pochodzi od Boga, może być pozyskana w wyniku dziedziczenia lub podboju. Współcześnie oczekuje się jednak racjonalności w karaniu i legitymowaniu władzy ${ }^{3}$. Dominuje pragnienie, aby władza miała uzasadnienie w umowie społecznej, w demokracji. 
Jean Jacques Rousseau wskazywał, iż legitymowana władza oznacza coś innego niż jedynie siłę czy przymus. Wskazywał, że „Najsilniejszy nie jest nigdy dość silnym, by zostać zawsze panem, jeżeli nie przekształci swej siły w prawo i posłuszeństwa w obowiązek” i dalej: „Ponieważ żaden człowiek nie ma władzy naturalnej nad innym człowiekiem i ponieważ siła nie tworzy nigdy prawa pozostają więc układy, jako podstawa wszelkiej władzy prawnej między ludźmi”4. Wolności nie oddaje się jednak darmo. Wolność jest człowiekowi przyrodzona. „Zrzec się swojej wolności, to znaczy zrzec się swego człowieczeństwa, praw ludzkości, nawet swoich obowiązków". Rousseau w umowie społecznej (contrat social) upatrywał odpowiedzi na problem znalezienia takiej formy zrzeszenia, która by „broniła i chroniła całą siłą wspólną osobę i dobra każdego członka, i przy której każdy, łącząc się ze wszystkimi, słuchałby jednak tylko siebie i pozostał równie wolnym jak poprzednio". Warunki umowy społecznej w istocie sprowadzić można do jednego, fundamentalnego: zupełnego oddania się każdego członka społeczności ze wszystkimi jego prawami całemu społeczeństwu, a ponieważ każdy oddaje się w zupełności, sytuacja jest równa dla wszystkich, nikt nie ma interesu czynić ją uciążliwą dla innych ${ }^{5}$. Rousseau uważał, że ponieważ oddanie następuje bez zastrzeżeń związek jest doskonały, jak tylko być może i żaden członek nie ma nic do żądania ${ }^{6}$. Kontrakt jest jasny, choć absolutny: wszystko za wszystko.

Przypomnienie fundamentów filozoficznych współczesnej demokracji jest konieczne, gdyż płyną z nich również istotne wnioski co do źródeł, granic i uzasadnienia państwowego karania ${ }^{7}$. Nie wymyślono jak dotąd lepszego systemu tworzenia i funkcjonowania prawa jak państwo demokratyczne. Oparciem zaś demokracji jest społeczność wyznająca określony system wartości. Doświadczenia XX wieku, często niezwykle bolesne, dowodzą, iż nie ma prawa i państwa demokratycznego bez społeczności, która w nie wierzy i ich broni. Jak zauważyła Hannah Arendt: „,nie utrata określonych praw, ale utrata społeczności, gotowej i będącej w stanie zagwarantować jakiekolwiek prawa, była nieszczęściem" że demokracja umożliwia urzeczywistnienie wartości doniosłych w życiu społecznym. Dzieje się tak również dlatego, że demokracja nie jest neutralnym ustrojem politycznym. Demokracja instytucjonalizuje w polityce bardziej etyczne traktowanie jednostek w zdecydowanie większym stopniu niż jej polityczne alternatywy, w tym zwłaszcza autokracja i oligarchia9.

Por. J.J. Rousseau, Umowa społeczna, przełożył i objaśnił dr Antoni Peratiatkowicz prof. Uniwersytetu Poznańskiego, wydanie 2, Poznań 1920, s. 14-15.

Ibidem, s. 20-21.

Ibidem.

Por. A. Peretiatkowicz, Filozofia prawa Jana Jakóba Rousseau’a, Kraków 1913, s. 218 i n. (zwłaszcza Rozdział V pt. Filozofia karna).

H. Arendt, Korzenie totalitaryzmu, t. 1, Warszawa 1993, s. 325.

Por. A. Gutmann, Identity in Democracy, Princeton 2004, s. 27; por. szerzej B. Wojciechowski, Interkulturowe prawo karne. Filozoficzne podstawy karania w wielokulturowych społeczeństwach demokratycznych, Toruń 2009 , s. 128 i n. 
Zagrożeniem dla demokracji jest brak zaangażowania obywateli w procesy demokratyczne. Ludzie czują się alienowani i pomijani ${ }^{10}$, gdyż ich głos liczy się jedynie w czasie wyborów. To duże zagrożenie. Demokracja nie jest ustrojem danym raz na zawsze. Trzeba o nią zabiegać i z mozołem budować kapitał społeczny. Jak słusznie zauważył John Braithwaite „ludzie nie rodzą się demokratami”"11, lecz uczą się różnorakich form demokratycznego uczestnictwa. Historia zna wiele form legitymizacji, lecz w dzisiejszym świecie jedynym poważnym jej źródłem jest demokracja ${ }^{12}$. Również Francis Fukuyama dowodzi oczywistej prawdy, że nie ma demokracji bez demokratów ${ }^{13}$. Wyjściem z marazmu we współczesnym modelu państwa demokratycznego jest większy udział samych obywateli, za sprawą deliberatywnego udziału w rządzeniu. Potrzeba „demokracji jako kooperacji” ${ }^{4}$, „demokracji partnerstwa”15.

Obywatele winni mieć swój udział nie tylko we władzy ustawodawczej, wykonawczej, ale również winni mieć swój udział we władzy sądowniczej, w sądzeniu, w stosowaniu prawa przez sądy. W każdym z trzech filarów władzy udział, partycypacja obywateli jest niezbędna. Dla zachowania równowagi nie wystarcza proste równoważenie się władz. Współcześnie, jak zauważa Braithwaite, potrzeba bardziej pluralistycznej wizji równowagi demokratycznej. Demokracji budowanej „od dołu”, która będzie hybrydowa: uwzględniająca głosy obywateli i w tym sensie deliberatywna, ale również kontestująca (contestatory democracy). Contestatory democracy to demokracja otwarta na debatę, nikogo niewykluczająca ${ }^{16}$.

Braithwaite ma rację, podkreślając szerokie znaczenie demokracji, gdyż to właśnie z demokracji, praw człowieka i rządów prawa (rule of law) wywodzi się tzw. normatywną legitymację do karania ${ }^{17}$.

Współcześnie znaczenie terminu „prawo karne” jest coraz to bardziej umowne ${ }^{18}$. Niemal dokładnie wiek temu, J. Makarewicz stwierdzał, że: „nazwa «prawo karne» odpowiada dawniejszemu sposobowi społecznego zapatrywania się na stanowisko: skoro wyrządzono przestępstwo należy karać. Kultura nowożytna oddala nas od tego stanowiska" ${ }^{19}$. Wskazywał na generalne łagodzenie sankcji, na coraz częstsze odstępowanie od karania. I chociaż Autorowi nie chodziło jeszcze o sprawiedliwość na-

10 Por. zwłaszcza R.D. Putnam, Samotna gra w kręgle. Upadek i odrodzenie wspólnot lokalnych w Stanach Zjednoczonych, Warszawa 2008.

11 J. Braithwaite, Deliberative Republican Hybridity Trough Restorative Justice, „Raisons politiques. Etudes de pensée politique" 2015, nr 59, s. 42.

12 F. Fukuyama, Budowanie państwa. Władza i ład międzynarodowy w XXI wieku, Poznań 2005, s. 42.

13 F. Fukuyama, Koniec historii, Kraków 2009, s. 201 i n. Demokracja współczesna ma wielu gorących przeciwników por. np. H.-H. Hoppe, Demokracja - bóg, który zawiódł. Ekonomia i polityka demokracji, monarchii i ładu naturalnego, Warszawa 2006.

14 Por. J. Dewey, The Public and Its Problems. An Essay in Political Inquiry, 2012.

15 Por. R. Dworkin, Is democracy possible here? Principles for a New Political Debate, 2006, s. 131 i n.

16 Por. J. Braithwaite, Deliberative..., op. cit., s. 33 i n.

17 Por. S. Snacken, Legitimacy of Penal Policies. Punishment between normative and empirical legitimacy, (w:) A. Crawford, A. Hucklesby (red.), Legitimacy and Compliance in Criminal Justice, London - New York 2013, s. 61 in.

18 Por. bliżej W. Zalewski, Sprawiedliwość naprawcza, (w:) T. Kaczmarek (red.), System Prawa Karnego. Tom 5. Nauka o karze. Sądowy wymiar kary, Warszawa 2014, s. 177 i n.

19 J. Makarewicz, Prawo karne ogólne, Kraków 1914, s. 1. 
prawczą, to trafnie zwracał uwagę na te wątki rozwojowe, które okazały się trwałe i do których nawiązuje się również współcześnie. W naukach penalnych wciąż aktualne są pytania o to, co zyskuje społeczeństwo przez sam fakt ukarania, rozważa się wszystkie korzyści i niekorzyści wymierzenia kary in concreto, podkreśla się znaczenie prewencji kryminalnej. Już przeszło stulecie temu pojawiły się propozycje posługiwania się bardziej adekwatnym terminem niż „prawo karne”. Proponowano np. „prawo zwalczania przestępstwa” ${ }^{20}$.

Tak jak zmienia się prawo karne, tak zmienia się pojmowanie sprawiedliwości. Sprawiedliwość zemsty, oparta o retrybutywne pojmowanie tego co się należy (suum quique), sprawiedliwość talionu, „oko za oko”, odegrała swoją rolę i słusznie odchodzi w przeszłość. Od dawna głosi się potrzebę odmiennego pojmowania sprawiedliwości. Nils Christie postulował sprawiedliwość opartą o współuczestnictwo ${ }^{21}$, co spotkało się z szerokim, pozytywnym odzewem ${ }^{22}$. Ten model sprawiedliwości postrzega przestępstwo przede wszystkim jako zakwestionowanie wartości społecznych, które wymaga przywrócenia naruszonych norm i naprawę wartości (value restoration). Proces ten może się odbyć poprzez odnowienie społecznej zgody odnośnie zasad i wartości. Chodzi o durkheimowską rewalidację wartości poprzez społeczną zgodę ${ }^{23}$. W tym ujęciu, sprawiedliwość oznacza naprawę wartości oraz kształtowanie społecznych postaw.

We współczesnym społeczeństwie indywidualna wolność uzyskała tak wielką wartość, że przestępstwo i powstały konflikt wymaga rozwiązania przez same strony, a nie tego, by państwo go rozstrzygało. Myślenia raczej w kategoriach cywilistycznych niż prawnokarnych w dotychczasowym ujęciu. W tej perspektywie wolność zostaje przeciwstawiona Państwu. Jak mówi N. Christie: państwo ukradło stronom ich konflikt, teraz musi go zwrócić ${ }^{24}$. To wypieranie państwowego przymusu z kształtu kary przedstawia się według N. Eliasa jako element procesu cywilizacji, jako forma wysubtelnienia społecznej kontroli. Na tej drodze od kary na życiu i wolności poprzez kary pieniężne zmierza się ku naprawieniu szkody i zadośćuczynieniu ${ }^{25}$.

Sprawiedliwość naprawcza (dalej: RJ) definiuje problem sprawiedliwości poprzez proces oraz wynik konkretnej sprawy. RJ włącza osoby, których głos był dotąd pomijany w procesie wymiaru sprawiedliwości. Oprócz sprawcy aktywną rolę pełnią ofiary, rodziny stron, sąsiedzi, a niekiedy, jak w konferencjach sprawiedliwości

Por. A. Thomsen, Grundriss Des Deutschen Verbrechensbekämpfungsrechtes, Enthaltend Das Deutsche Straf- Und Sonstige Bekampfungsrechts: Besonderer Teil, Struppe \& Winckler, 1905 (podaję według wydania z 2010 roku).

Por. N. Christie, Granice cierpienia, Warszawa 1991, s. 112 i n.

Jedynie anglojęzyczne opracowania naukowe na ten temat liczone są w tysiącach. Por. np. publikacje wymienione na: http://restorativesolutions.us/resources/best-restorative-justice-books.

Por. M. Wenzel, I. Thielmann, Why We Punish in the Name of Justice: Just Desert versus Value Restoration and the Role of Social Identity, „Social Justice Research” 2006, Tom 19, nr 4, s. 450 i n.

Por. N. Elias, Über den Prozeß der Zivilisation, Band 1 i 2, 16, 1991, za: D. Dölling, Der Täter - Opfer - Augleich - Möglichkeiten und Grenzen einer neuen kriminalrechtlichen Reaktionsreform, JZ 1992, nr 10, s. 495. 
naprawczej również przedstawiciele wspólnot lokalnych. Powodzenie procesu mierzone jest stopniem satysfakcji osób, dla których drzwi zostały otwarte. Sprawiedliwość naprawcza jest krytyczna, co wyraża się przede wszystkim brakiem zaufania do profesjonalnych przedstawicieli wymiaru sprawiedliwości oraz tradycyjnych sformalizowanych procedur. Jednak, sprawiedliwość naprawcza odnosi się do poszczególnej sprawy kryminalnej i jeśli zostaje ona w sposób satysfakcjonujący zamknięta, uznaje się, iż zakładane cele zostały osiągnięte ${ }^{26}$.

W wielu publikacjach podkreśla się związki sprawiedliwości naprawczej z ideałami republikanizmu ${ }^{27}$ oraz wskazuje się na ogromne możliwości RJ (restorative justice) w zakresie krzewienia demokracji. Podkreśla się, że „Jednym z powodów, dla których sprawiedliwość naprawcza jest tak popularna jest to, że za jej pomocą mały kawałek władzy zostaje zwrócony zwyczajnym ludziom" ${ }^{28}$. W tym sensie sprawiedliwość naprawcza opowiada się za ograniczeniem państwowego ius puniendi, a tym samym roli władzy państwowej w karaniu. Chodzi o wymiar sprawiedliwości oparty o szerokie i aktywne uczestnictwo różnie pojmowanych wspólnot (communities). Okazało się bowiem, że istnieją silne związki między modelem sprawowania władzy a wymiarem sprawiedliwości. Jeśli są oparte na uczestnictwie i konsensusie, kształtują odpowiedzialność i postawy obywatelskie. System punitywny nie uczy demokracji, nie uczy, jak być obywatelem. Każe być biernym. Biernie przyjmować odpowiedzialność, znosić sprawiedliwość, a nie w niej uczestniczyć. Formy sprawiedliwości naprawczej takie jak kręgi i konferencje jako procedury restorative justice (RJ) uczą aktywnej odpowiedzialności. Dają nadzieję, że można zmienić sytuacje, że można ją uzdrowić. Tu wszyscy uczestnicy mają głos, który coś znaczy. Uczą elementarza demokracji - bezpośredniego uczestnictwa ${ }^{29}$. Sprawiedliwość naprawczą przedstawia się jako oddolny przykład deliberacji obywatelskiej w praktyce. Wskazuje się na zbieżność procedur RJ z procedurami tak ostatnio dyskutowanej demokracji deliberatywnej ${ }^{30}$. W obu przypadkach na pierwszy plan wybija się potrzeba świadomej partycypacji, wzajemnego szacunku uczestników oraz zgodnego porozumienia ${ }^{31}$.

Restorative justice to sprawiedliwość krzepiąca, wzmacniająca strony. Strategia wzmocnienia przez pojednanie umożliwia lokalnym społecznościom wyjście naprzeciw ich potrzebie pokoju. Wzmocnienie ofiar pozwala im wyjść naprzeciw ich

26 A. Crawford, T.R. Clear, Community Justice: Transforming Communities through Restorative Justice?, (w:) E. McLaughilin, R. Fergusson, G. Hughes, L. Westermarland (red.), Restorative Justice. Critical Issues, 2003, s. 215.

27 Por. J. Braithwaite, P. Pettit, Not Just Deserts: A Republican Theory of Criminal Justice, Cambridge 1990; J. Braithwaite, Restorative Justice and Responsive Regulation, New York 2002; J. Braithwaite, Relational republican regulation, „Regulation and Governance” 2013, nr 7(1), s. 124-144.

28 J. Braithwaite, Encourage Restorative Justice, „Criminology and Public Policy” 2007, nr 6, s. 689.

29 Por. J. Braithwaite, Democracy, Community And Problem Solving, http://www.realjustice.org /Pages/vt99papers/ vt_brai_html.

30 Por. J. Parkinson, D. Roche, Restorative Justice: Deliberative Democracy in Action?, „Australian Journal of Political Science" 2004, nr 39(3), s. 506 i n.

31 Por. szerzej K. Kim, Restorative Justice and Deliberative Democracy: Connecting and Clarifying Foundational Norms Paper presented at the annual meeting of the MPSA Annual National Conference, Palmer House Hotel, Hilton, Chicago, IL, Apr 03, 2008, http://www.allacademic.com/meta/p265841_index.html. 
potrzebie kontroli i porządku. Wzmocnienie sprawcy umożliwia mu zaakceptować odpowiedzialność i pozwala mu stać się odpowiedzialnym. Strategia wzmocnienia kreuje potencjał dynamicznych i innowacyjnych rozwiązań problemów tworzonych przez przestępstwo, włączając w to kreowanie norm społecznych. RJ wyrasta $\mathrm{z}$ konkretnych doświadczeń, podkreśla się konieczność dokonywania badań, eksperymentów potwierdzających słuszność jej ideałów. Mimo krytyki starego paradygmatu, nikt w zasadzie nie głosi potrzeby całkowitego odrzucenia starych instytucji. Pozostawia się margines spraw, które powinny być załatwione według starego modelu ${ }^{32}$. Jest jasne, że sprawiedliwość restaurująca bardzo różni się od naszego represyjnego i punitywnego systemu sprawiedliwości, opartego na idei posłuszeństwa. Przestępstwo pojmuje się jako konflikt. Podkreśla się, że rozmiar, charakter i przyczyny nieomal każdego konfliktu kryminalnego wskazują, że dotychczasowe strategie wzmocnienia poprzez włączenie pokrzywdzonych w system sprawiedliwości karnej, np.: mediacje i restytucje, muszą sięgać dalej i nie wyczerpywać się w ułatwianiu zawarcia ugody przez strony uczestniczące w sporze. Strukturalne rozmiary konfliktu wskazują na konieczność przyjęcia bardziej ambitnego ujęcia sprawiedliwości. Istota modelu restauracyjnego wyraża głębokie zainteresowanie nie tylko naprawą szkody wyrządzonej w przeszłości, ale również stworzeniem lepszej przyszłości. Przyszłości, w której ludzie żyją w poprawnych materialnych, socjalnych i duchowych relacjach ze sobą. Ta przyszłość wymaga głębokiego wglądu w czynniki przyczyniające się do przestępstwa, tworzące konflikt i niesprawiedliwość, wymaga działania, które je złagodzi lub wyeliminuje.

Robert Putnam dowiódł na podstawie swych prawie dwudziestoletnich badań, że podstawą demokracji jest zaangażowanie obywatelskie: „być obywatelem we wspólnocie oznacza przede wszystkim aktywnie uczestniczyć w sprawach publicznych" ${ }^{33}$. Pełne zaangażowanie obywatelskie zapewnia demokracja deliberatywna inaczej zwana partycypacyjną, gdzie o każdej ważnej społecznej sprawie współdecydują obywatele ${ }^{34}$.

Podobnie jak w programach restorative justice również $\mathrm{w}$ demokracji deliberatywnej istnieje możliwość wielowariantowości. Wymienia się tu programy: 1. Obywatelskie ławy przysięgłych (Citizens Juries), 2. Głosowania deliberatywne opinii (Deliberative Opinion Pools), 3. Konferencje konsensualne (consensus conferences), 4. Interaktywne zespoły dyskusyjne (Standing panels: interactive panels), 5. Wspólnotowe grupy problemowe (Community Issue Groups), 6. Badawcze zespoły dyskusyjne

Nawet H. Bianchi odszedł od swego pierwotnego radykalizmu i głosi zasadę „Wzajemnego ograniczania” obu systemów. Por. bliżej o tym H. Bianchi, Justice As Sanctuary. Toward a New System of Crime Control, Eugene, Oregon,1994.

33 R.D. Putnam, Demokracja w działaniu. Tradycje obywatelskie we współczesnych Włoszech, Kraków 1995, s. 133 in.

34 Por. przede wszystkim: P.W. Juchacz, Idea demokracji deliberatywnej, (w:) M.N. Jakubowski, A. Szachaj, K. Abriszewski (red.), Indywidualizm, Wspólnotowość, Polityka, Toruń 2002; P.W. Juchacz, Obywatelstwo, tożsamość, partycypacja: o idei demokracji deliberatywnej na szczeblu lokalnym, (w:) R. Piekarski (red.), Lokalna wspólnota polityczna a zagadnienie tożsamości zbiorowej, Kraków 2002. 
(Standing panels: reaserch panels), 7. Demokracja elektroniczna (Electronic democracy \& methodology), 8. Konferencje dla przyszłości (Future search conferences), 9. Planowanie dla rzeczywistości (Planning for Real), 10. Publiczne zaangażowanie dzieci i młodzieży (Children, Young People \& Public Involvement) ${ }^{35}$. Wszystkie te programy cechuje: 1) innowacyjność, 2) informatywność (poszukują kompetentnego, poinformowanego stanowiska publicznego), 3) deliberatywność (decyzje i opinie osiągane przez interaktywną dyskusję), 4) niezależność, 5) demokratywność - konsultujące opinie zwyczajnych obywateli (a nie polityków, czy ekspertów) ${ }^{36}$. W Polsce wykorzystywane są niektóre z nich - bodaj najczęściej spotkania deliberacyjne, np. „Zszywanie miasta" w Łodzi $^{37}$.

Widać stąd, że związki między sprawiedliwością naprawczą a demokracją deliberatywną są bliskie.

Wspomniane relacje zyskują na sile, gdy uświadomić sobie, że przedmiotem debaty demokratycznej może się stać i staje się również karanie ${ }^{38}$. Postuluje się szeroki udział obywateli w wymiarze sprawiedliwości karnej. Jak powiada Albert W. Dzur: „Normalny, regularny, aktywny udział obywateli w ramach instytucji jest niezbędny współczesnemu społeczeństwu dla świadomego uznania i przyjęcia odpowiedzialności za wymiar sprawiedliwości karnej” ${ }^{39}$. Nie wszystkie przestępstwa dają się zamknąć pojednaniem stron, są sprawy, w których kara jest niezbędna ${ }^{40}$, a sprawiedliwość naprawcza nie jest możliwa. Możliwy jest jednak udział lokalnej wspólnoty (community justice). Sprawiedliwość wspólnotowa ogniskuje swoje zainteresowanie na innym poziomie; chodzi tu w pierwszym rzędzie o to, w jaki sposób sprawa karna, dany czyn, wpłynął na życie lokalnej wspólnoty, pojmowanej w większym stopniu w kategoriach sąsiedztwa. Podejmowane strategie działania oceniane są pod katem tego, jak wpływają na lokalną wspólnotę $e^{41}$. Sprawiedliwość wspólnotowa posługuje się szerszym wachlarzem strategii obejmujących również działania prewencyjne, które nie mieszczą się w schematach restorative justice. Do prewencyjnych metod angażujących obywateli należy przykładowo zapobieganie przestępczości poprzez odpowiednie zagospodarowanie przestrzeni (Crime Prevention Trough Environmental Design) ${ }^{42}$.

$35 \quad$ Ibidem, s. 66.

36 Omawiam za ibidem. Por. również dane ze strony internetowej Institute for Public Policy Research: www.ippr.org. uk. Ostatnio A. Krzewińska, Deliberacja. Idea - metodologia - praktyka, Łódź 2016. Autorka omawia szerzej: 1/ sondaż deliberatywny, 2/ sądy obywatelskie, 3/ spotkania miejskie XXI wieku, 4/ techniki otwartej przestrzeni, 5/ kawiarenki deliberacyjne - ibidem, s. $115 \mathrm{i} \mathrm{n}$.

37 Por. ibidem, s. 165 i n.

38 Por. P. de Greiff, Deliberative Democracy and Punishment, „Buffalo Criminal Law Review” 2002, vol. 5; A.W. Dzur, Participatory Democracy and Criminal Justice, Criminal Law and Philosophy, June 2012, s. 115 i n., A.W. Dzur, Punishment, Participatory Democracy, and the Jury, Oxford 2012.

39 A.W. Dzur, The Priority of Participation: a Friendly Response to Professor Gargarella, Criminal Law and Philosophy, September 2016, s. 476.

40 Por. W. Zalewski, Przestępca „niepoprawny” - jako problem polityki kryminalnej, Gdańsk 2010.

41 A. Crawford, T.R. Clear, Community Justice..., op. cit., s. 216.

42 Por. zwłaszcza J. Czapska (red.), Zapobieganie przestępczości przez kształtowanie przestrzeni. Teoria. Badania. Praktyka, Kraków 2012. 
W tym miejscu może jednak powstać pytanie; jeśli nadal karzemy sprawców tyle, że z szerszym niż dotychczas udziałem obywateli to, jaka jest różnica w porównaniu $z$ dotychczasowym modelem? Otóż, różnica jest znacząca i leży w stopniu akceptacji prawa przez wszystkich, których to dotyczy. Pełna akceptacja może być osiągnięta jedynie w wyniku otwartej i wolnej debaty ${ }^{43}$. Mówiąc szerzej: przechodzenie na pozycje konsensualne jest charakterystyczne dla współczesnego państwa demokratycznego. Według Nicholasa Thimasheffa obserwujemy poszerzanie się elementu etycznego (konsensus) kosztem elementu władzy (przymus). We współczesnych koncepcjach państwa proces ten uwidacznia się w procesie demokratyzacji. Gdyby koncepcje państwa umieścić na skali, przyjmując jako kryterium porządkujące rolę przymusu prawnokarnego, to utworzyłyby one pewne conntinuum od koncepcji państwa totalitarnego, w którym przemoc jest wszechogarniająca, poprzez różne koncepcje państwa autorytarnego, po demokratyczne koncepcje państwa, czy „państwa dobrobytu” minimalizujące rolę przymusu prawnokarnego i zastępujące je nowymi formami przymusu $^{44}$. Mało tego, we współczesnym zinformatyzowanym świecie demokracja bezpośrednia korzysta z nowych form komunikacji. Obywatele łączą się między sobą nie tylko ponad mediami, lecz i ponad politycznymi podziałami. Powstaje nowa jakość: demokracja partycypacyjna, gdzie debata jest kształtowana od dołu, a obywatele są wolni ${ }^{45}$.

Czas na pewne podsumowanie. Na postawione w tytule niniejszego tekstu pytanie należy odpowiedzieć twierdząco. Sprawiedliwość naprawcza jest formą realizacji demokracji partycypacyjnej.

Odpowiedzialność za czyn przestępczy wzbudza i wzbudzać będzie społeczne zainteresowanie. Można je różnie wykorzystać. Może to być niezdrowa ciekawość, żądza sensacji, na której żerują niektóre media ${ }^{46}$. Dziś mówi się przecież pesymistycznie o sprawiedliwości tabloidowej, kreowanej przez media, wpływające na kształt i stosowanie prawa ${ }^{47}$. Zainteresowanie sprawą karną można jednak wykorzystać pozytywnie, poprzez stworzenie deliberatywnych ram dla realizacji założeń sprawiedliwości opartej na współuczestnictwie.

P. de Greiff, Deliberative democracy..., op. cit., s. 377. Por. też P. Pettit, Deliberative Democracy and the Doctrinal Paradox oraz R.E. Goodin, Democratic Deliberation Within, referaty przygotowane na Deliberating about Deliberative Democracy Conference at the Law School, University of Texas, 4-6 February 2000.

44 A. Gryniuk, Przymus prawny. Studium socjologiczno-prawne, Toruń 1994, s. 76.

45 Por. D. Morris, Direct Democracy and the Internet, Loyola of Los Angeles Law Review, April 2001, s. 1033 i n.

46 Por. Y. Jewkes, Media i przestępczość, Kraków 2010, s. 36 i n. Autorka wskazuje, że: „Nawet najbardziej pobieżne badanie medialnego relacjonowania przestępczości ukazuje, że informacje o przestępczości rozmijają się zarówno z „rzeczywistością” przestępczości, jak i z jej reprezentacją w oficjalnych statystykach”.

47 Por. R.L. Fox, R.W. van Sickel, T.L. Steiger, Tabloid Justice. Criminal Justice in an Age of Media Frenzy, London 2007. Autorzy konkludują pesymistycznie: "Any reform efforts that are aimed simply at regulating media behavior or restricting press access to the courts and to police activities undoubtedly would have little impact on the tabloid justice environment. Many of the dynamics of the situation are far more complicated than simply the irresponsible conduct of the news media. Popular culture, commercial imperatives, and a complacent and unengaged citizenry have all converged to produce this set of problems" (s. 206). 
Proces wyżej zarysowany nie oddziela jednostki od dbającej o nią wspólnoty, nie rozdziela racjonalności od emocji, sprawiedliwości od potrzeb. Nie polega również na ocenach ekspertów. Raczej - gdy przestępcze zachowanie stworzyło sprawcę i ofiarę - RJ daje najbardziej dotkniętym możliwość poszukiwania rozwiązania. Dostają szansę, na którą jego uczestnicy w pełni zasługują. Zmierzając do pokojowego wyjścia z konfliktu, sprawiedliwość restaurująca stara się personalizować konflikt, odpowiedzialność i uczestniczące strony celem wyrażenia i przekształcenia silnych emocji doświadczanych przez ofiarę, sprawcę i wspólnotę w związku z przestępstwem. Ten rodzaj wyjścia z przestępstwa obejmuje wysiłek i zaangażowanie ze strony jednostek. Ale wymaga również społecznego tła, zaangażowania ze strony wspólnoty. W społeczeństwie podkreślającym wartość obywatelskiego zaangażowania w sprawy państwa, zwiększenie obywatelskiego uczestnictwa nie wymaga dalszych usprawiedliwień ${ }^{48}$. Jak to nieco poetycko powiedział Lode Walgrave „rozszerzająca się rzeka sprawiedliwości naprawczej tworzy u swego ujścia żyzną deltę, która nawadnia wysychającą demokrację poprzez budzenie partycypacyjnego uczestnictwa obywateli, którzy biorą na siebie odpowiedzialność za poszukiwanie konstruktywnych rozwiązan'"49.

\section{Bibliografia}

Arendt H., Korzenie totalitaryzmu, t. 1, Warszawa 1993.

Bianchi H., Justice As Sanctuary. Toward a New System of Crime Control, Eugene, Oregon 1994.

Braithwaite J., Deliberative Republican Hybridity Trough Restorative Justice, „Raisons politiques. Etudes de pensée politique" 2015, nr 59.

Braithwaite J., Democracy, Community And Problem Solving, http://www.realjustice.org /Pages/ vt99papers/vt_brai_html.

Braithwaite J., Encourage Restorative Justice, „Criminology and Public Policy” 2007, nr 6.

Braithwaite J., Pettit P., Not Just Deserts: A Republican Theory of Criminal Justice, Cambridge, 1990.

Braithwaite J., Relational republican regulation, „Regulation and Governance” 2013, nr 7(1).

Braithwaite J., Restorative Justice and Responsive Regulation, New York 2002.

Christie N., Conflicts as property, „The British Journal of Criminology” 1977, nr 17.

Christie N., Granice cierpienia, Warszawa 1991.

Crawford A., Clear T.R., Community Justice: Transforming Communities through Restorative Justice?, (w:) E. McLaughilin, R. Fergusson, G. Hughes, L. Westermarland (red.), Restorative Justice. Critical Issues, 2003.

48 B. Galaway, Informal justice: Mediation between offenders and victims, (w:) P. Albrecht, O. Backes (red.), Crime Prevention and Intervention: Legal and Ethical Problems, New York 1989, s. 112.

49 Por. L. Walgrave, Restorative justice, Self - interest and Responsible Citizenship, Willan Publishing 2008, s. 196. 
Czapska J. (red.), Zapobieganie przestępczości przez kształtowanie przestrzeni. Teoria. Badania. Praktyka, Kraków 2012.

Dewey J., The Public and Its Problems. An Essay in Political Inquiry, 2012.

Dölling D., Der Täter - Opfer - Augleich - Möglichkeiten und Grenzen einer neuen kriminalrechtlichen Reaktionsreform, JZ 1992, nr 10.

Dworkin R., Is democracy possible here? Principles for a New Political Debate, 2006.

Dzur A.W., Participatory Democracy and Criminal Justice, Criminal Law and Philosophy, June 2012.

Dzur A.W., Punishment, Participatory Democracy, and the Jury, Oxford 2012.

Dzur A.W., The Priority of Participation: a Friendly Response to Professor Gargarella, Criminal Law and Philosophy, September 2016.

Elias N., Über den Prozeß der zivilisation, Band 1 i 2, 16, 1991.

Fox R.L., van Sickel R.W., Steiger T.L., Tabloid Justice. Criminal Justice in an Age of Media Frenzy, London 2007.

Fukuyama F., Budowanie państwa. Władza i ład międzynarodowy w XXI wieku, Poznań 2005.

Fukuyama F., Koniec historii, Kraków 2009.

Galaway B., Informal justice: Mediation between offenders and victims, (w:) P. Albrecht, O. Backes (red.), Crime Prevention and Intervention: Legal and Ethical Problems, New York 1989.

Goodin R.E., Democratic Deliberation Within, referat przygotowany na Deliberating about Deliberative Democracy Conference at the Law School, University of Texas, 4-6 February 2000.

de Greiff P., Deliberative Democracy and Punishment, „Buffalo Criminal Law Review” 2002, vol. 5.

Gryniuk A., Przymus prawny. Studium socjologiczno-prawne, Toruń 1994.

Gutmann A., Identity in Democracy, Princeton 2004.

Hoppe H.-H., Demokracja - bóg, który zawiódł. Ekonomia i polityka demokracji, monarchii i ładu naturalnego, Warszawa 2006.

Jewkes Y., Media i przestępczość, Kraków 2010.

Juchacz P.W., Idea demokracji deliberatywnej, (w:) M.N. Jakubowski, A. Szachaj, K. Abriszewski (red.), Indywidualizm, Wspólnotowość, Polityka, Toruń 2002.

Juchacz P.W., Obywatelstwo, tożsamość, partycypacja: o idei demokracji deliberatywnej na szczeblu lokalnym, (w:) R. Piekarski (red.), Lokalna wspólnota polityczna a zagadnienie tożsamości zbiorowej, Kraków 2002.

Kim K., Restorative Justice and Deliberative Democracy: Connecting and Clarifying Foundational Norms Paper presented at the annual meeting of the MPSA Annual National Conference, Palmer House Hotel, Hilton, Chicago, IL, Apr 03, 2008, http://www.allacademic.com/meta/ p265841_index.html.

Krzewińska A., Deliberacja. Idea - metodologia - praktyka, Łódź 2016.

Lipset S.M., Homo politicus: społeczne podstawy polityki, Warszawa 1995.

Makarewicz J., Prawo karne ogólne, Kraków 1914. 
Morris D., Direct Democracy and the Internet, Loyola of Los Angeles Law Review, April 2001.

Parkinson J., Roche D., Restorative Justice: Deliberative Democracy in Action?, „Australian Journal of Political Science" 2004, nr 39(3).

Peretiatkowicz A., Filozofia prawa Jana Jakóba Rousseau’a, Kraków 1913.

Pettit P., Deliberative Democracy and the Doctrinal Paradox, referat przygotowany na Deliberating about Deliberative Democracy Conference at the Law School, University of Texas, 4-6 February 2000 .

Putnam R.D., Demokracja w działaniu. Tradycje obywatelskie we współczesnych Włoszech, Kraków 1995.

Putnam R.D., Samotna gra w kręgle. Upadek i odrodzenie wspólnot lokalnych w Stanach Zjednoczonych, Warszawa 2008.

Rousseau J.J., Umowa społeczna, przełożył i objaśnił dr Antoni Peratiatkowicz prof. Uniwersytetu Poznańskiego, wydanie 2, Poznań 1920.

Snacken S., Legitimacy of Penal Policies. Punishment between normative and empirical legitimacy, (w:) A. Crawford, A. Hucklesby (red.), Legitimacy and Compliance in Criminal Justice, London New York 2013.

Thomsen A., Grundriss Des Deutschen Verbrechensbekämpfungsrechtes, Enthaltend Das Deutsche Straf- Und Sonstige Bekampfungsrechts: Besonderer Teil, Struppe \& Winckler, 1905.

Walgrave L., Restorative justice, Self-interest and Responsible Citizenship, Willan Publishing 2008.

Wenzel M., Thielmann I., Why We Punish in the Name of Justice: Just Desert versus Value Restoration and the Role of Social Identity, „Social Justice Research” 2006, Tom 19, nr 4.

Wojciechowski B., Interkulturowe prawo karne. Filozoficzne podstawy karania w wielokulturowych społeczeństwach demokratycznych, Torun 2009.

Wróblewski B., Penologia. Socjologia kar, Tom I, Wilno 1926.

Zalewski W., Przestępca „niepoprawny” - jako problem polityki kryminalnej, Gdańsk 2010.

Zalewski W., Sprawiedliwość naprawcza, (w:) T. Kaczmarek (red.), System Prawa Karnego, Tom 5, Nauka o karze. Sądowy wymiar kary, Warszawa 2014.

Zieliński E., Nauka o państwie i polityce, Warszawa 2001. 